\title{
The Evaluation of Block Grant Program
} Implementation at Teacher Working Group (Kelompok Kerja Guru or KKG) of Natural Science in Gorontalo District

\author{
Nina Lamatenggo ${ }^{1}$, Rusdin Kadjim ${ }^{2}$, Keysar Panjaitan ${ }^{3, *}$, Hamzah B. Uno \\ ${ }^{1}$ Department of Education Management, Faculty of Social Science, State University of Gorontalo, Gorontalo, Indonesia. \\ ${ }^{2}$ Gorontalo Province Education and Training Agency, Gorontalo, Indonesia. \\ ${ }^{3}$ Department of Mechanical Engineering Education, Faculty of Engineering, State University of Medan, Medan, Indonesia. \\ ${ }^{4}$ Department of Mathematics Education, Faculty of Mathematics and Natural Science, State University of Gorontalo, Gorontalo, \\ Indonesia. \\ *Correspondence: pkeysar9@gmail.com
}

\begin{abstract}
The objective of this research was to find out how to evaluate the implementation of the block grant program at Teacher Working Group of Natural Science in Gorontalo District as an effort to improve the learning process. This research used qualitative analysis approach to describe various matters related to the focus of research. The type of research was program evaluation using the CIPP (Context, Input, Process, and Product) model. The main technique of data collection applied interviews, observation and documentation of various data sources (informants) with a direct correlation with the use of block grant fund in KKG activities and their implementation in the learning process. The research findings on the evaluation of implementation of block grant program in KKG of Natural Science in Gorontalo District could be concluded from the observation that the researcher has worked based on the expectation where the block grant fund has been used as well as possible for KKG activities, yet certain things required improvement in its implementation. (1) In the context evaluation, it found that there were two KKG that did not have vision and mission in which it illustrated that these groups had not been able to carry out their functions optimally. (2) In the Input evaluation, the obstacles were encountered by management of KKG where numerous activities of KKG could not be proposed considering that insufficient block time and funding (3) In the Process Evaluation, it found that some groups said that inadequate block grant fund for all KKG program activities and most KKG did not know the national education standards. (4) In the Product Evaluation, the obstacles encountered by teachers were the number of students in one class had exceeded the standard. In addition, some teachers admitted that they did not make the lesson plan themselves instead of other people did it even some made the Lesson Plan after completing the teaching.

Keywords-Evaluation, Teacher Working Group or KKG, Block Grant, Natural Science.
\end{abstract}

\section{INTRODUCTION}

To improve the quality of teaching and learning at schools particularly in the classroom, a teacher is required to be able to understand, master, and practice the prevailing curriculum. In the recent era, there are three challenges faced by teachers in implementing the curriculum; challenges in the fields of curriculum management, learning, and assessment. In facing these challenges, it will rely on the professionalism of teacher. The professional teachers will be able to organize a fun learning process for students and teachers and be able to think in accordance with the prevailing rules so that it can encourage the growth of learning creativity in students.
The selection of the correct learning model will also greatly determine the interests and participation of students in learning. The appropriate learning model, students are expected not only to gain knowledge but also have a deep impression on the learning topic, thus it can encourage students to implement the concepts of subject values in daily life. To overcome this, a forum should be formed to help solve the previous problems, namely the Teacher Working Group (KKG) for elementary school level.

In general, KKG activities can provide benefits as a place for discussion and problem solving for teachers who experience difficulties in learning activities. The problems encountered by teachers within the learning 
process in the classroom are varied in the forms and models. Consequently, it requires diverse solution too to handle them. It is understandable that all teachers are not well-experienced as senior teachers who might have more techniques and ways of dealing with problems, especially teaching and learning problems. For this reason, new teachers or other teachers who have problems which according to them are difficult can be solved through the KKG by discussing and sharing experiences with other teachers.

In relation to the previous cases, the Ministry of National Education implements KKG revitalization program through Block Grant for teachers through the KKG forum. The Block Grant is expected to be able to encourage profession activities in the forum to improve teacher competency based on the Government Regulation number 19 of 2005 on the National Education Standard. Furthermore, through the activities in this forum, it is hoped that there will be an increase in the performance and professionalism of teachers which eventually can provide fairly significant contribution to the improvement of entire quality of education.

Block grant is a number of funds provided by the government to a particular forum or institution which should be optimally utilized in accordance with the guidelines set by the government. The KKG block grant is temporary and limited. The temporary category means that the funds are given within a certain period to support the implementation of the program planned by the KKG while limited means that the funds are only intended for $\mathrm{KKG}$ and met certain requirements. The KKG Block grant is based on a desire to help the forum in developing and implementing various programs and activities related to the education process (particularly the learning process) which aim to improve student achievement. The funding of block grant to KKG in Gorontalo District has been ongoing since 2006 until present. Therefore, it is necessary to evaluate the implementation of the block grant program in Teacher Working Group (KKG) in Gorontalo District as an effort to improve the learning process.

\section{Research question}

1. How is the implementation of KKG activities as an effort to improve the science learning process in Gorontalo District through block grant funds?

2. What are the obstacles and solution of block grant program in the implementation of KKG activities in order to improve the science learning process in Gorontalo District?

\section{THEORETICAL DESCRIPTION}

1. Definition of Evaluation
Evaluation is the process of gathering, analyzing, and interpreting information obtained to determine whether something works so that it can be used to make decisions. Decision making related to evaluation is an action taken by a person or institution in order to improve or perfect certain program. Evaluation can be used to check the level of success of a program related to program scope to achieve decision (judgment), whether or not the program is continued, postponed, increased, institutionalized, accepted or rejected/ terminated.

Context evaluation (context) is a description and specification of the program environment, unfulfilled needs, population characteristics, and samples of individuals served and program objectives. Evaluation of input (input) helps organize decisions, determine available sources, alternatives which are taken, plans and strategies to achieve goals, and work procedures to achieve them. The input evaluation component includes a) human resources, b) Supporting facility and equipment c) Funds/ budgets and d) Various procedures and rules needed. Process evaluation is used to detect or predict procedure designs or implementation plans during the implementation phase, provide information for program decisions and as a record or archive of procedures that have occurred. Product evaluation (product) is an assessment conducted to measure success in achieving the set goals. The generated data will determine whether the program is continued, modified or terminated.

\section{Definition of Block Grant}

Block grant is a number of funds provided by the government to a particular forum or institution which should be optimally utilized in accordance with the guidelines set by the government. The KKG revitalization block grant is designed to assist teachers in developing and implementing various programs and activities related to learning and management process. The grant is expected to support the improvement of quality of education and enable the KKG to choose programs which meet the special needs for learning and management/ administration that support the learning process of students at schools.

The KKG block grant is temporary and limited. This means that block grant is given to support the implementation of programs that have been planned by the $\mathrm{KKG}$ in certain period of time for certain subjects. The block grant is also a stimulus which means the KKG needs to explore other sources of funds. Block grant is used to finance the operation of various programs according to the KKG's tasks, functions, and responsibilities. Block grant management must be done transparently and accountably.

Block grant is used for the activities such as implementable curriculum/ syllabus development that is in 
accordance with competency standards in related subjects, Development of competency-based teaching materials in related subjects, Development of appropriate, interesting and fun learning methods, CTL, Development of appropriate, interesting and fun learning media for related subjects, Making quality teaching props for related subjects, Research and development, especially classroom action research, which is meaningful to improve the quality of learning, Developing learning skills for the next meeting, Life skills and questioning techniques, Writing of Scientific Work, the development of profession and career of teachers and classroom assessment systems.

\section{Understanding Teacher Working Groups}

Teacher Working Group (KKG) is a forum/ organization or group of subject teachers who have special activities in providing educational information in order to improve the personal quality of teachers in the teaching and learning process. The Teacher Working Group (KKG) is a forum for teacher professional development that can be used to communicate, exchange ideas and share experiences, perform various demonstrations, attractions, and simulations in the learning. KKG is an active, unified, and familiar professional forum for teachers. In this forum the teachers can discuss problems from and for them.

Teacher working group (KKG) is a workgroup which is oriented to improvement of knowledge quality, material mastery, teaching techniques, student-teacher interactions, teaching methods, and others that focus on creating active teaching and learning activities.

\section{RESEARCH METHODOLOGY}

\section{A. Research Time and Site}

This research was conducted for 3 months, from the preparation to the report creation in the form of a thesis. The time was planned from April to June 2015.

\section{B. Research Subjects}

The subjects of this study were all the Teacher Working Group (KKG) of natural science in Gorontalo District. The KKG was selected due to it has received Block Grant fund from the Ministry of National Education. This research was conducted for 3 months, from the preparation to the report creation in the form of a thesis. The time was planned from April to June 2015.

\section{Research Approaches and Types}

This study used qualitative analysis approach. Meanwhile, the type of research was program evaluation using CIPP (Context, Input, Process, and Product) model which was first offered by Stufflebeam in 1965. The program evaluation is one type of object of evaluation research. The fundamental orientation in all evaluation studies is the benefit.
This evaluation research is directed at the results of the block grant product. However, the other three components were also evaluated, because the four components had a very close relationship. Thus, the data collected would be analyzed with an inductive/ qualitative approach (for data from context, input, process and product evaluation). This was done because there was a high enough chance of determining the value of something, based on predetermined benchmarks (criteria).

\section{Data and Data Sources}

Data on the implementation of KKG activities as an effort to improve the learning process. Information in the research was obtained from the Chair and Management of KKG in Natural Sciences in Gorontalo District. Sources of data were obtained at each unit of analysis (context, input, process, and product) by triangulation method and focus group discussion (FGD) which involved all members of KKG of Natural Sciences in Gorontalo District.

\section{E. Data Collection Techniques}

The techniques of data collection applied in this research were interviews, observation, and documentation.

According to Faisal (1994: 62), the techniques of data collection in qualitative research commonly used interview that were (1) unstructured, (2) conducted blatantly, and (3) place informants as peer investigators. Therefore, the main technique of data collection in this research was interview with all informants.

In conducting interviews, researchers were guided by interview guidelines that were open, which meant that the answers given by respondents were free of the questions asked (instruments attached).

Instead of the interview, the data collection was also performed by using observation and documentation techniques. The observation technique was carried out on the process and product (results) of the block grant implementation program in KKG of Natural Science in Gorontalo District, while the documentation technique was carried out on certain documents associated with the process and product (results).

\section{F. Data Analysis}

This research approach was qualitative research so that the data analysis technique was used was qualitative. In qualitative research, the data analysis technique used was the inductive analysis technique (Faisal 1990: 19), which meant that it started from the fact to a higher level of abstraction, including synthesizing and developing theory.

Therefore, the research was conducted through the following steps sequentially:

1. Data Reduction

a) Make a contact summary 
b) Develop coding categories

c) Data selection

2. Data Presentation

3. Conclusion Drawing

G. Validity Check of Findings/ Conclusions

In checking the validity of research findings, the following data testing procedures were performed:

1. Testing through triangulation technique

2. Member check.

\section{DISCUSSION}

$\mathrm{KKG}$ is a forum for teachers to gather at school group to solve problems, try and develop new ideas to improve the quality of Teaching and Learning Activities and improve teacher professionalism. Meanwhile, school meeting is a meeting of a group of teachers from one school, who regularly gather at the school and led by the Principal to solve their own problems

In an effort to improve teacher competency, especially science subjects, the exchange of experience and information sharing between teachers through $\mathrm{KKG}$ forum is held. The existence of KKG is very strategic as the effort to realize the improvement of teacher competency in managing natural science learning, but the prominent obstacles faced by the KKG are lack of activity management funds and lack of variety and quality of program activities.

Since 2006, the Ministry of National Education through LPMP Gorontalo has implemented KKG revitalization program through block grant, which aimed to broaden teachers' insights and knowledge in various ways, particularly mastering the substance of learning materials, syllabus preparation, learning material preparation, learning strategy, learning method, maximizing learning facilities/ infrastructure, utilizing learning resources and so forth.

Block grant fund provided to the $\mathrm{KKG}$ in Gorontalo District began in 2006, and the amount of fund was IDR.10.000.000 (tax included) and transferred to the KKG account, and all the KKG that were examined have received the block grant funds.

The mechanism of distributing block grant was started with socialization from LPMP Gorontalo and Education Agency of Gorontalo District, then each KKG management sent an application letter addressed to the Head of LPMP and approved by the Education Agency of the District.

The application letter attached:

1. The proposal was in accordance with the determined systematic.
2. A photocopy of the KKG Statutes/ Bylaws including the management organizational structure approved by the Education District of District.

3. Statement letter of ability to use block grant for the implementation of the KKG program with duty stamp IDR. 6000 according to format.

4. Photocopy of Certificate of Completion of Education and Training (STTPP) of Guide Teacher or Core Teacher/ Instructor/ Subject Developer.

5. Photocopy of a bank account in the name of $\mathrm{KKG}$ (not in the management's personal name).

6. Photocopy of school tax ID number which was the KKG secretariat or one of the schools of KKG member who were a prospective recipient of block grant.

7. Declaration letter of not receiving a block grant from other agencies within the PMPTK Directorate General (LPMP/ PPPPTK/ Dit.Bindiklat/ Dit. Tendik/ Dit PTK PNF/ Dit Profesi Pendidik/ Setditjen PMPTK) with duty stamp IDR.6000 according to format.

8. Entering the KKG e-mail address or management for smooth communication

After the proposal was accepted, LPMP would hold a selection. The selection was done in two stages. The first stage was administrative requirement and the second stage was an assessment of proposal content. If the participant was declared to have passed stage one, thus the process continued to stag two. The selection results were announced on the LPMP website and a notification from the Education Agency of Gorontalo District. In this case, $\mathrm{KKG}$ which met the requirement and passed the selection would be contacted by LPMP for signing the MoU and disbursing funds.

KKG who had received block grant and had carried out activities must report the implementation of activities funded by block grant to LPMP and the report covered academic and financial implementation.

Based on the researcher observation, the results of the evaluation of the implementation of block grant program in the KKG of Natural Science in Gorontalo District have been running in accordance with the expectation where the block grant fund has been used as well as possible for KKG activities. However, several things needed to be improved in the implementation. The following described the implementation of $\mathrm{KKG}$ activities as an effort to improve the science learning process in Gorontalo District through block grant fund as well as obstacles and solutions to the implementation of KKG activities in terms of 
improving the science learning process in Gorontalo District.

\section{Implementation of KKG activities as an effort to improve the Natural Science learning process in Gorontalo District through block grant fund}

\section{a. Context}

In accordance with the vision of $\mathrm{KKG}$ management, the realization of recognized professional organizations for improvement is the competence and career of teachers in organizing education so that it can be implemented effectively and efficiently, in fact some KKG have realized their vision in implementing activity programs as an effort to improve the natural science learning process in Gorontalo District, likewise, the management mission is to create an active and effective working group and play a role in all activity, improvement of quality of the learning process that leads to improving the quality of education as a whole, fostering culture of research among educators, broadening teachers' insight in the use and mastery of ICT, providing opportunity and service for KKG members to improve the development of teachers' professionalism in accordance with needs, improving skills knowledge and adopt renewal approach to learning that is more professional for working group participants in accordance with the competencies required for teachers and students, namely academic, pedagogical, personal and social competencies, motivating teachers to improve their knowledge and skills in the field of information and communication technology (ICT) for the benefit of learning, utilizing the potential of teachers in educating and train students to be able to learn directly to become qualified, advanced and independent human beings in the corridors of faith and piety (Imtaq), creating intelligent teachers who master science and technology, creating innovative, dedicated, responsible and professional teachers, creating active, innovative, creative, effective and fun learning, creating culture-based learning that reflects individual differences, realizing reliable human resources through $\mathrm{KKG}$ activities and utilizing the potential of teachers in educating and training students to be able to learn directly to become human beings with quality, advanced and independent character in the corridors of faith and piety (Imtaq). The management mission has been carried out in all KKG activities and implemented in the teaching and learning process.

The background of the program in KKG activities was the difference or lack of understanding of teachers in the preparation of learning set such as difference in the preparation of syllabus, difference in the preparation of lesson plan, learning development and difference in the preparation of evaluation material, as well as ignorance on the use of teaching props.

Meanwhile, the purpose of the block grant program in KKG activities was to improve the quality of learning commenced from improving teachers' competency, improving the ability of teachers to carry out learning, improving the ability of teachers in mastering science and technology, encouraging teachers' skills in writing scientific paper, providing assistance and coaching services related to the task of educating, teaching, training, improving the professional competence of teachers in managing learning proportionally. The objectives of the KKG management have been performed in KKG activities and have been implemented in the learning process.

\section{b. Input}

The Teacher Working Group in Gorontalo District was established around 2002 funded by membership fee from IDR. 2,500 to IDR. 5,000 and contained around 50 to 180 members. Of all the members to date, one remains active, and four of the two KKG people have been rotated. The number of clusters was different for each sub-district. In detail, Timur and Selatan Districts sub-districts consisted of 5 clusters, each cluster covered 5 to 6 schools, while for Tengah, Barat and Utara Districts sub-districts, only 3 clusters consisted of 5 to 6 schools as well. Then, Dungingi District consisted of 2 clusters. The recruitment of members of some KKG requires only civil servants, and some even require that they have been a member of certain organization.

The Proposal of KKG activity program began with a notification from the Agency and then was discussed by the management and members which involving committee of the head of cluster, Principal, and elements of branch of Agency. The result of discussion (musyawarah) was submitted to members and made proposals submitted to the Agency and LPMP while the disbursed fund was notified to members. The programs proposed by KKG members were only limited for important activities because of the fund. The proposed program of the KKG activities commenced with a meeting of the core management with the school principals per cluster, discussing the program to be included in the KKG, proposals from the school principal and core management were accommodated only for the important ones. All parties were given the opportunity then determine the scale of priority through the program framer team.

The priority in the preparation of KKG program was started from the beginning of the school year and preparing for learning set such as the preparation of lesson 
plan, syllabus, teaching material, the learning started with learning simulations, making media \& learning tools while making improvements. End of the school year covered the making of blueprint and question bank including their revision.

\section{c. Process}

The program and activity in KKG were scheduled according to the number of activities and the duration was around one to two days. KKG activities were guided by good informants/ interviewees from elements of the Ministry of National Education, education practitioners and LPMP widyaiswara (a type of special Civil Servant).

In general, KKG activity discussed KBM or teaching and learning activity issues, for example teaching preparation, including making activity steps, making and testing learning aids, and Peer Teaching.

Forms of KKG activity in Gorontalo District included: preparation of learning media, use of appropriate methods in learning, making teaching props and environmental or natural media, introduction of CAR for teachers to the preparation of proposals and introduction of ICT, learning programs for semester 2 and 9, subjects for all classes, compiling the second semester test questions, developing curriculum for SBK subjects (arts and culture skills), developing local content teaching material, socializing pakem (pembelajaran aktif kreatif efektif dan menyenangkan or active, creative, effective and fun learning) learning model and technique of compiling question, making learning media, designing assessment technique, modeling peer teaching (modeling based on IMTAQ), compiling daily test questions and semester tests, making teaching props, teacher modeling, preparation of thematic lesson plan for class 1,2,3 and innovative and non innovative lesson plan for class 4,5,6, Socialization of scientific paper for group IV teachers, designing simple props for Natural Science subject, Indonesian Language Learning Workshop, compiling question for semester I at class I to VI for all subjects, minimum completeness criteria, Lesson study and Preparation of teaching material.

Initially, the KKG activities only discussed the preparation of repetition questions due to lack of funds to finance the activities. However, the presence of block grant assistance program from the Ministry of National Education thus all groups prioritized activities that were indispensable to facilitate teaching and learning at schools.

The purpose of block grant program in KKG was to facilitate the activities of the KKG and to improve teachers competence in implementing the learning such as educating, teaching, training so that it could improve the quality and learning process.
Some KKG in Gorontalo District received block grant for two to three times on average, except one KKG that only received one time. The distribution of the fund in KKG was adjusted to the need of each activity, and this was recorded in accordance with the financial statement of each KKG. All KKG managements mentioned that the block grant funds were very effective for all activities but still coordinated with the principal's Group Work or KKKS with other donor sources. The other sources of funding from the government or other agencies for $\mathrm{KKG}$ activities, instead of block grant from LPMP, were from sponsors such as teachers who were married to members of the House of Representative, then the sponsors provide facilities such as fan or IDR. 500.000 (non-routine) for only once in a while, there was also another assistance besides the block grant from LPMP which was assistance from the district government for IDR. 5.000.000 in 2006.

\section{d. Product}

Implementation of the $\mathrm{KKG}$ activity program could improve teacher competency in managing learning, teachers could understand the learning techniques of pakem model, teachers mastered the use of teaching props or learning media. In the learning process, its implementation could improve the quality and learning process in which it was seen from the activities of students in following the learning process and also improved student graduation and the success of Semester Final Test.

Based on the researcher observation, the results of the implementation of KKG activities have been carried out. This was evidenced by reports on the implementation of activities in the form of academic and financial implementation. For instance, there were annual program and semester program, syllabus and lesson plan that has been compiled, the result of the teachers' scientific paper, teaching props that have been made, questions that have been prepared, textbooks that have been made.

In the implementation of learning, the researcher has conducted direct observation on the core school where temporary learning took place. The teachers who were teaching have conducted the learning according to the lesson plan and syllabus that have been prepared.

2. Obstacles and solution of block grant program in the implementation of KKG activities in the context of improving Natural Science learning process in Gorontalo District

a. Context

The finding of research in KKG in Gorontalo District found that there were two groups that did not have vision and mission who illustrated that the groups have not been able to perform its functions optimally due to the 
planning of activities that have been formulated a vision integrated with the mission, and objectives were summarized in separate chapter. The vision is an insight that is a source of direction for the KKG and is used to guide the formulation of KKG mission. In other words, vision is a far-sighted approach to where KKG activities will be taken. Vision is a picture of the future desired by KKG so that the KKG can guarantee its survival and development. Meanwhile, the mission is an action to realize the vision. Therefore, the formulation accommodated all KKG activities.

According to the two groups who did not have the vision and mission, they had not had time to make a vision and mission because of the busyness of all members in performing teaching and learning tasks but the group stated that they had group goals in performing programs in $\mathrm{KKG}$ and the KKG objectives have been performed in KKG activities and have been implemented in the teaching and learning process.

\section{b. Input}

The obstacles faced by KKG management members were that many activities that were proposed in KKG program activities could not be approved due to considering insufficient block time and funding, so the solution taken by KKG management was to prioritize only the very important and very urgent programs.

\section{c. Process}

All KKG said that the block grant fund was very effective for all activities but was not sufficient for all needs related to the implementation of learning at school. The efforts of KKG in meeting the fund was to limit activities that were considered most important to be performed in the KKG program. Other efforts from some groups said that the group requested assistance from the Education Agency of District or from members of the House of Representative to fund the activities. The expectation of the group from the $\mathrm{KKG}$ was to improve number of the upcoming years block grant assistance.

Another obstacle faced by members in the implementation of KKG activities was the time to do these activities. In addition, the group was difficult to determine the time due to a large number of tasks from school in the teaching and learning process. Also, another obstacle was that there were also some teachers who were late when the activity has been started. The solution was to do activities when learning hours have finished and the application of discipline to members who arrived late when $\mathrm{KKG}$ activities were ongoing.

The result of interview from all KKG found that some teachers did not know the National Education Standards, as teachers who were professional in fulfilling the duties of every teaching staff were required to meet education management standards that applied nationally, as presented in number of regulation whose purpose is to control national education policies, such as Government Regulations number: 19 of 2005 concerning on national education standards which manage 8 (eight) national education standards. It was hoped that by implementing the 8 national education standards, Indonesian education could answer global demands. The 8 national education standards were: content standard, process standard, graduate competency standard, teacher and education staff standard, facility and infrastructure standard, management standard, financing standard, and education assessment standard.

\section{d. Product}

The obstacle faced by the KKG in implementing it was that there were teachers who did not have time to teach because there were some teachers who were temporarily continuing their studies, but the effort of KKG itself was to replace teachers who were unable to attend with other teachers in the same subject, and also replacing the time out of school hours or giving assignments to students.

The obstacle faced in some schools was the number of students in each class that exceeded the standard of 30 people, and there were even 40 people for each class. The effort of the school to solve it was to repeat the subjects whose grades were poor on students to meet the KKM (minimum completeness criteria)

Another obstacle faced by some groups was the making of Lesson Plan (RPP) and difficult to operate a computer. These were also caused by condition where they should make Lesson Plan for each class differently because of paying attention to differences in gender, initial ability, intellectual level, interest, learning motivation, talent, potential, social ability, emotion, learning style, special need, speed of learning, cultural background, norm, values, and/ or the environment of students. Therefore, the lesson plans held by some teachers were only made by others and some teachers even mad lesson plan when class was finished.

\section{CONCLUSIONS}

The results of the evaluation of the implementation of block grant program in KKG of Natural Science in Gorontalo District have been running based on the expectation where the block grant fund has been used as well as possible for KKG activities. However, several things needed to be improved in the implementation. 
1. Implementation of KKG activities as an effort to improve Natural Science learning process in Gorontalo District through block grant fund

a. Context

This was in accordance with the vision, mission, objectives, and background of KKG has been performed in all the KKG activities and implemented in the teaching and learning process in the context of improving the quality and learning process.

b. Input

The priority in the preparation of $\mathrm{KKG}$ program was started from the beginning of the school year and preparing for learning set such as the preparation of lesson plan, syllabus, teaching material, the learning started with learning simulations, making media \& learning tools while making improvements. End of the school year covered a blueprint and question bank including revisions.

\section{c. Process}

The program and activity in KKG were scheduled according to the number of activities and the duration was around one to two days. KKG activities were guided by good informants/ interviewees from elements of the Ministry of National Education, education practitioners and LPMP widyaiswara (type of special Civil Servant).

\section{d. Product (Product)}

Based on the researcher observation, the results of the implementation of KKG activities have been carried out. For instance, there were annual program and semester program, syllabus and lesson plan that has been compiled, the result of the teachers' scientific paper, teaching props that have been made, questions that have been prepared, textbooks that have been made. During the learning, teachers have run the class in accordance with Lesson Plan and syllabus that have been compiled.

2. Obstacles and solution of block grant program in the implementation of KKG activities in the context of improving the science learning process in Gorontalo District

\section{a. Context}

The finding of research in KKG in Gorontalo District found that there were two groups that did not have vision and mission. According to the two groups who did not have the vision and mission, they had not had time to make a vision and mission because of the busyness of all members in performing teaching and learning tasks but the group stated that they had group goals in performing programs in $\mathrm{KKG}$ and the $\mathrm{KKG}$ objectives have been performed in $\mathrm{KKG}$ activities and have been implemented in the teaching and learning process.

\section{b. Input}

The obstacles faced by KKG management members were that many activities that were proposed in KKG program activities could not be approved due to considering insufficient block time and funding, so the solution taken by KKG management was to prioritize only the very important and very urgent programs.

\section{c. Process}

The block grant fund was very effective for all activities but was not sufficient. The effort of groups was requesting assistance from the Education Agency of District or from members of the House of Representative. Another obstacle faced by members in the implementation of KKG activities was the time to do the activities and some teachers who were late when the activity has been started. The solution was to do activities when learning hours have finished and the application of discipline to members. Additionally, some teachers did not know the National Education Standards.

\section{d. Product}

The obstacle faced by the KKG in implementing it was time of teachers due to some teachers who were temporarily continuing their studies, but the effort of KKG itself was to replace teachers who were unable to attend with other teachers in the same subject, and also replacing the time out of school hours or giving assignments to students. The obstacle faced by other schools was the number of students in each class that exceeded the standard of 30 people, and there were even 40 people for each class. The effort of the school to solve it was to repeat the subjects whose grades were poor on students to meet the KKM (minimum completeness criteria). Another obstacle faced by some groups was the making of Lesson Plan (RPP) as the teachers were difficult to operate computer while they should make the Lesson Plan for each class differently because of paying attention to differences in gender, initial ability, intellectual level, interest, learning motivation, talent, potential, social ability, emotion, learning style, special need, speed of learning, cultural background, norm, values, and/ or the environment of students. Therefore, the lesson plans held by some teachers were only made by others and some teachers even mad lesson plan when class was finished.

\section{ACKNOWLEDGEMENTS}

This study intends to express gratitude to the Rector of the State University of Gorontalo and the Head of the Gorontalo State University Research Institute for providing this study through the Research Institute. 


\section{REFERENCES}

[1] Abbas, Nurhayati. (2006). Hubungan Antara Minat Terhadap profesi Guru, Keinovatian Guru, Dan Pengalaman Diklat Dengan Kompetensi Profesional Guru Matematika SMP Negeri Di Provinsi Gorontalo, Disertasi Program Pascasarjana Universitas Negeri Jakarta.

[2] Baumgartner, Ted A \& Andrew S Jackson. (1975). Measurement for Evaluation in physical Education and Exercise Scienc, fifth edition : United States of america by Wm C Brown Comunication, Inc

[3] Brinkerhoff, Robert O. et. all. (1986). Program Evaluation: A Practitioner's Guide for Trainers and Educators. Fourth edition. Boston: Kluwer Nijhoff Publishing.

[4] Crocker dan Algina. (1986). Instruction to Classical and Modem Test Theory, New York, Holt Rinehart and Winston, Inc

[5] Cronbach. (1970). Essential of Psychologycal Testing New York: Harper and Brother Publisher.

[6] Departemen Pendidikan Nasional. (2009). Pedoman Penyaluran Bantuan Langsung (Block Grant) Dalam Rangka Pelaksanaan Revitalisasi KKG dan MGMP,LPMP Gorontalo.

[7] Gay. (1970). Educational Evaluation and Measurement, Competencies for Analysis and Application, Colombus Ohio: Charles E. Merril Publishing Company, A Bell and Howell Company.

[8] Gronlund, Norman E and Rober L.Linn. (1985). Measurement and Evaluation in teaching, $6^{\text {th }}$ edition. New York: macmillan Publishing Company.

[9] Isaac, Stephen and William B. Michael. (1981). Handbook in Research and Evaluation. Second edition San Diego California: Edits Publisher.

[10] Joint Committee on standards for Educational Evaluation. (1981). Standars for Evaluations of Educational Programs, Projects, and Materials, New York; McGraw-Hill Book Company,

[11] Julia, Ratna. (2000). makalah : Pengembangan Kelompok Kerja Guru, Padang, KKG Padang Barat.

[12] Madaus, George F, Michael S. Scriven, and Daniel L Stuffebeam. (1983). Evaliation Models: Viewpoints on Educational and Human services Evaluation, Boston: Kluwer-Nijhoff Publishing.

[13] Morse, Janice M. (1994). "Designing Funded Qualitative Reasearch" dalam Norman K Denzim dan Yvonna S. Lincoln. Handbook of Qualitative Research. California: SAGE Publicayions, Inc.

[14] Popham, W. James., 1987, Educational Evaluation, New Jersey : Prentice-Hall, Inc.

[15] Putro Widoyoko, Eko. (2009). Evaluasi Program Pembelajaran, Yogyakarta : Pustaka Pelajar.

[16] Silverius. (1991). Evaluasi Hasil Belajar dan Umpan Balik. (Jakarta: Penerbit PT Grasindo/

[17] Stufflebeam, Daniel L and Anthony J. Shinkfield., 1986, Systematic Evaluation: A Self-Instructional Guide to Theory and Practice ( Boston: Kluwer-Nijhoff Publishing.

[18] Hamzah B. Uno, Keysar Panjaitan, Nina Lamatenggo, Kasim Yahidji, The Leadership Style Of Headmaster
inGuiding Characters in the Public Senior High School 2 Limboto., International Journal of Advenced Enginering, Managenet and science 9jarms) Vol-5, Issue 3, Mart-2019.

[19] Wahyudin. Din. (1995). Monitoring dan Evaluasi Petunjuk bagi Para Pelaksana, (Jakarta: PEQIP.

[20] Winkel. (2009). Psikologi Pengajaran. Yogyakarta : Media Abadi.

[21] Worthen, Blaine R. and James R. Sanders. (1987). Educational Evaluation, Alternative Approaches and Practical Guidelines. New York \& London: Longman Inc. 